\title{
Pengaturan Suhu Tubuh dengan Metode Tepid Water Sponge dan Kompres Hangat pada Balita Demam
}

\author{
NLP Yunianti Suntari $\mathbf{C}^{\mathbf{1}}$, Putu Susy Natha Astini ${ }^{2}$, Ni Made Desi Sugiani ${ }^{3}$ \\ 1,2,3 Jurusan Keperawatan, Politeknik Kesehatan Denpasar, Indonesia \\ Email: yuni.suntari@yahoo.com
}

\begin{abstract}
Control The Body Temperature with Tepid Water Sponge and Warm Compress Method for Children Under Five Years having a Fever. Fever is a condition of an increase in body temperature. High fever can cause many complications. The purpose of this research was to know the difference of effectiveness of tepid water sponge and warm compress method to control the body in children under five years having a fever. This research was used quasi-experimental design and non-equivalent control group design. The number of samples in each group was 30 people selected by consecutive sampling technique. The result of the average temperature drop in the tepid water sponge group was $0.993^{\circ} \mathrm{C}$, while the average temperature drop in the warm compress group was $0,54^{\circ} \mathrm{C}$. The result of this research was used paired-samples t-test and independent-samples t-test and obtained $\mathrm{p}$-value $=0,0001(p<0,05)$. There was a difference of effectiveness of tepid water sponge and warm compress method to control the body temperature in children under five years with fever at Puskesmas Abiansemal I and Puskesmas Mengwi I Year 2018.
\end{abstract}

Keywords: Compress, Fever, Tepid water sponge

\begin{abstract}
Abstrak: Pengaturan Suhu Tubuh dengan Metode Tepid Water Sponge dan Kompres Hangat pada Balita Demam. Demam merupakan kondisi terjadinya kenaikan suhu tubuh. Demam tinggi dapat menimbulkan banyak komplikasi. Tujuan penelitian ini adalah untuk mengetahui perbedaan efektivitas metode tepid water sponge dan kompres hangat terhadap pengaturan suhu tubuh pada anak usia balita dengan demam. Jenis penelitian ini menggunakan quasi eksperimental design dengan rancangan Non-equivalent Control Group Design. Jumlah sampel pada masing-masing kelompok yaitu 30 orang yang dipilih dengan teknik Consequtive Sampling. Hasil analisis rata-rata penurunan suhu pada kelompok tepid water sponge yaitu $0,993^{\circ} \mathrm{C}$, sedangkan pada kelompok kompres hangat yaitu $0,54^{\circ} \mathrm{C}$. Hasil penelitian diuji dengan paired-samples $t$-test dan independentsamples $t$-test didapatkan hasil $p=0,0001(p<0,05)$. Ada perbedaan efektivitas metode tepid water sponge dan kompres hangat terhadap pengaturan suhu tubuh pada anak usia balita dengan demam.
\end{abstract}

Kata kunci: Kompres, Demam, Tepid water sponge

\section{PENDAHULUAN}

Demam merupakan kondisi terjadinya kenaikan suhu tubuh hingga $>37,5^{\circ} \mathrm{C}$. Ikatan Dokter Anak Indonesia menetapkan suhu tubuh normal untuk anak berkisar antara $36,5^{\circ} \mathrm{C}$ sampai $37,5^{\circ} \mathrm{C}$ (Setiawati, 2009). Pada demam tinggi dapat terjadi alkalosis respiratorik, asidosis metabolik, kerusakan hati, kelainan EKG, dan berkurangnya aliran darah otak. Dampak lain yang dapat ditimbulkan jika demam tidak ditangani maka akan dapat menyebabkan kerusakan otak, hiperpireksia yang akan menyebabkan syok, epilepsi, retardasi mental atau ketidakmampuan belajar (Ganong, 2002).

Di Bali, penyakit yang didahului dengan demam yang sering terjadi yaitu demam berdarah dengue, ISPA, penyakit paru, demam thypoid, dan parathypoid. Penyakit tersebut merupakan bagian dari pola sepuluh besar penyakit pada pasien di Puskesmas dan RSU Bali (Dinas Kesehatan Provinsi Bali, 2016). Pada tahun 2015 kasus demam berdarah dengue berjumlah 10.704 kasus, meningkat pada tahun 2016 berjumlah 21.668 kasus, dan mengalami penurunan pada tahun 2017 berjumlah 3.986 kasus (Dinas Kesehatan Provinsi Bali). Badung merupakan kabupaten di Bali dengan jumlah kasus demam tertinggi ketiga pada tahun 2017. Kasus demam di Puskesmas Abiansemal I Badung tahun 2017 sebanyak 861 kasus, sedangkan di Puskesmas Mengwi I Gianyar tahun 2017 sebanyak 955 kasus. 
Penanganan terhadap demam dapat dilakukan dengan tindakan farmakologis, tindakan non farmakologis maupun kombinasi keduanya. Tindakan farmakologis yaitu memberikan obat antipiretik (Kania, 2007). Tindakan non farmakologis yaitu tindakan tambahan dalam menurunkan panas yang dilakukan setelah pemberian obat antipiretik (Kania, 2007). Kompres adalah salah satu tindakan non farmakologis untuk menurunkan suhu tubuh bila anak mengalami demam. Ada beberapa macam kompres yang bisa diberikan untuk menurunkan suhu tubuh yaitu tepid water sponge dan kompres air hangat (Dewi, 2016). Tepid water sponge merupakan alternatif teknik kompres yang menggabungkan teknik blok dan seka (Efendi, 2012). Kompres hangat merupakan tindakan menurunkan suhu tubuh dengan menggunakan kain atau handuk yang telah dicelupkan pada air hangat, yang ditempelkan pada bagian tubuh tertentu sehingga dapat memberikan rasa nyaman (Wardiyah, 2016).

Berdasarkan hasil penelitian Dede Mahdiyah, Topan Aditya Rahman, Aulia Dewi Lestari didapatkan kesimpulan bahwa kompres air hangat lebih efektif dibandingkan plester kompres dengan hasil nilai rata-rata suhu tubuh sebelum kompres hangat $38,14^{\circ} \mathrm{C}$ dan plester kompres $38,02^{\circ} \mathrm{C}$. Selisih suhu tubuh setelah dilakukan kompres hangat yaitu 1,10 dan plester kompres yaitu 0,42 (Mahdiyah, 2015). Adapun berdasarkan penelitian yang dilakukan oleh $S$ Thomas, C Vijaykumar, R Naik, Pd Moses, dan B Antonisamy didapatkan hasil bahwa penggunaan metode tepid sponging dan antipiretik dapat menurunkan suhu tubuh lebih cepat dibandingkan hanya menggunakan antipiretik saja (Thomas, 2009). Hasil serupa juga didapatkan pada penelitian yang dilakukan oleh João Guilherme Bezerra Alves; Natália Dornelas Câmara Marques de Almeida; Camila Dornelas Câmara Marques de Almeida bahwa tepid sponge lebih efektif 15 menit pertama dibandingkan jika hanya diberikan obat dypirone saja (Alves, 2008).

Berdasarkan uraian tersebut, peneliti tertarik melakukan penelitian tentang "Efektivitas Metode Tepid Water Sponge dan Kompres Hangat Terhadap Pengaturan Suhu Tubuh pada Anak Usia Balita dengan Demam di Puskesmas Abiansemal I dan Puskesmas Mengwi I". Tujuan penelitian ini adalah untuk mengetahui perbedaan efektivitas metode tepid water sponge dan kompres hangat terhadap pengaturan suhu tubuh pada anak usia balita dengan demam di Puskesmas Abiansemal I dan Puskesmas Mengwi I.

\section{METODE}

Penelitian ini merupakan penelitian kuantitatif dengan jenis penelitian quasieksperimental design dengan rancangan Nonequivalent Control Group Design. Penelitian ini menggunakan jumlah sampel yaitu 60 orang (30 orang untuk kelompok perlakuan dan 30 orang untuk kelompok kontrol). Kelompok perlakuan diberikan tindakan kompres tepid water sponge yang dilakukan di Puskesmas Abiansemal I, sedangkan kelompok kontrol diberikan tindakan kompres hangat yang dilakukan di Puskesmas Mengwi I. Pengukuran suhu dilakukan 3 kali yaitu sebelum dilakukan tindakan, 15 menit setelah tindakan, dan 30 menit setelah tindakan.

Teknik pengambilan sampel yang digunakan adalah dengan non-probability sampling yaitu consecutive sampling. Consecutive sampling yaitu teknik pengambilan sampel yang berdasarkan pada waktu penelitian (Sugiyono, 2015).

Analisa data diawali dengan analisa univariat untuk mendapatkan informasi sebaran data pada kedua kelompok. Baik itu hasil mean (rata-rata), nilai median (nilai tengah), nilai modus (suhu terbanyak yang muncul), suhu minimum dan suhu maksimum.

Berikutnya analisis bivariat. Analisis bivariat bertujuan untuk mengetahui perbedaan suhu sebelum dan sesudah dilakukan tindakan kompres tepid water sponge dan kompres hangat, serta untuk mengetahui perbedaan efektivitas pengaturan suhu tubuh menggunakan kompres tepid water sponge dan kompres hangat. Data yang diuji secara bivariat dalam penelitian ini adalah suhu sebelum tindakan dan suhu 30 menit setelah tindakan, serta nilai perubahan suhu dengan menggunakan kompres hangat dan kompres tepid water sponge. Diawali dengan memenuhi uji prasyarat analisis, didapat data berdistribusi normal sehingga uji yang digunakan yaitu paired-samples $t$ test (untuk mengetahui perbedaan suhu sebelum dan sesudah dilakukan tindakan kompres tepid water sponge dan kompres hangat) dan independent-samples t test (untuk mengetahui perbedaan efektivitas pengaturan suhu tubuh menggunakan kompres tepid water sponge dan kompres hangat).

\section{HASIL}

Variabel yang diukur dalam penelitian ini adalah suhu sebelum tindakan, suhu 15 menit setelah tindakan, dan suhu 30 menit setelah tindakan, serta dilakukan pengukuran untuk 
mengetahui karakteristik subyek penelitian. Hasil penelitian dapat digambarkan sebagai berikut :

Tabel 1. Karakteristik Responden berdasarkan Usia dan Jenis Kelamin pada Kelompok Tepid Water Sponge

\begin{tabular}{|c|c|c|}
\hline Karakteristik & f & $\%$ \\
\hline \multicolumn{3}{|c|}{ Usia (Tahun) } \\
\hline $1-2$ & 17 & 56,67 \\
\hline $2-3$ & 5 & 16,67 \\
\hline $3-4$ & 3 & 10 \\
\hline $4-5$ & 5 & 16,67 \\
\hline \multicolumn{3}{|c|}{ Jenis Kelamin } \\
\hline Laki-laki & 21 & 70 \\
\hline Perempuan & 9 & 30 \\
\hline
\end{tabular}

Tabel 1 menunjukkan bahwa usia subjek penelitian sebagian besar berada pada rentang usia 1-2 tahun yaitu sebanyak 17 orang $(56,67 \%)$ dan sebagian besar berjenis kelamin laki-laki yaitu sebanyak 21 orang $(70 \%)$.

Tabel 2. Karakteristik Responden Berdasarkan Usia dan Jenis Kelamin pada Kelompok Kompres Hangat

\begin{tabular}{|c|c|c|}
\hline Karakteristik & f & $\%$ \\
\hline \multicolumn{3}{|c|}{ Usia (Tahun) } \\
\hline $1-2$ & 19 & 63,3 \\
\hline $2-3$ & 5 & 16,7 \\
\hline $3-4$ & 6 & 20 \\
\hline $4-5$ & 0 & 0 \\
\hline \multicolumn{3}{|c|}{ Jenis Kelamin } \\
\hline Laki-laki & 18 & 60 \\
\hline Perempuan & 12 & 40 \\
\hline
\end{tabular}

Tabel 2 menunjukkan bahwa usia subjek penelitian sebagian besar berada pada rentang usia 1-2 tahun yaitu sebanyak 19 orang $(63,3 \%)$ dan sebagian besar berjenis kelamin laki-laki yaitu sebanyak 18 orang $(60 \%)$.

Tabel 3. Hasil Analisis Suhu Tubuh Responden Sebelum Tindakan Kompres Tepid Water Sponge

\begin{tabular}{lll}
\hline \multicolumn{1}{c}{ Variabel } & Mean & n \\
\hline $\begin{array}{l}\text { Suhu sebelum } \\
\text { tindakan }\end{array}$ & 38,61 & 30 \\
\hline
\end{tabular}

Tabel 3 menunjukkan hasil mean (ratarata) suhu tubuh sebelum dilakukan tindakan yaitu $38,61^{\circ} \mathrm{C}$ atau dibulatkan menjadi $38,6^{\circ} \mathrm{C}$

Tabel 4. Hasil Analisis Suhu Tubuh Responden 15 Menit Setelah Tindakan Kompres Tepid Water Sponge

\begin{tabular}{lcc}
\hline \multicolumn{1}{c}{ Variabel } & Mean & n \\
\hline $\begin{array}{l}\text { Suhu 15 menit } \\
\text { setelah tindakan }\end{array}$ & 38,11 & 30 \\
\hline
\end{tabular}

Tabel 4 menunjukkan hasil mean (ratarata) suhu tubuh 15 menit setelah dilakukan tindakan yaitu $38,11^{\circ} \mathrm{C}$.

Tabel 5. Hasil Analisis Suhu Tubuh Responden 30 Menit Setelah Tindakan Kompres Tepid Water Sponge

\begin{tabular}{ccc}
\hline Variabel & Mean & n \\
\hline $\begin{array}{l}\text { Suhu 30 menit } \\
\text { setelah tindakan }\end{array}$ & 37,61 & 30 \\
\hline
\end{tabular}

Tabel 5 menunjukkan hasil mean (ratarata) suhu tubuh 30 menit setelah dilakukan tindakan yaitu $37,61^{\circ} \mathrm{C}$ atau dibulatkan menjadi $37,6^{\circ} \mathrm{C}$

Tabel 6. Hasil Analisis Suhu Tubuh Responden Sebelum Tindakan Kompres Hangat

\begin{tabular}{rcc}
\hline \multicolumn{1}{c}{ Variabel } & Mean & n \\
\hline $\begin{array}{l}\text { Suhu sebelum } \\
\text { tindakan }\end{array}$ & 38,38 & 30 \\
\hline
\end{tabular}

Tabel 6 menunjukkan hasil mean (ratarata) suhu tubuh sebelum dilakukan tindakan yaitu $38,38^{\circ} \mathrm{C}$.

Tabel 7. Hasil Analisis Suhu Tubuh Responden 15 Menit Setelah Tindakan Kompres Hangat

\begin{tabular}{ccc}
\hline \multicolumn{1}{c}{ Variabel } & Mean & n \\
\hline $\begin{array}{l}\text { Suhu 15 menit } \\
\text { setelah tindakan }\end{array}$ & 38,10 & 30 \\
\hline
\end{tabular}

Tabel 7 menunjukkan hasil mean (ratarata) suhu tubuh setelah dilakukan tindakan yaitu $38,10^{\circ} \mathrm{C}$ atau dibulatkan menjadi $38^{\circ} \mathrm{C}$

Tabel 8. Hasil Analisis Suhu Tubuh Responden 30 Menit Setelah Tindakan Kompres Hangat

\begin{tabular}{lcc}
\hline \multicolumn{1}{c}{ Variabel } & Mean & n \\
\hline $\begin{array}{l}\text { Suhu } 30 \text { menit } \\
\text { setelah tindakan }\end{array}$ & 37,84 & 30 \\
\hline
\end{tabular}

Tabel 8 menunjukkan hasil mean (ratarata) suhu tubuh 30 menit setelah dilakukan tindakan yaitu $37,84^{\circ} \mathrm{C}$ atau dibulatkan menjadi $37,8^{\circ} \mathrm{C}$

Tabel 9. Hasil Analisis Suhu Tubuh Responden Sebelum dan Setelah Tindakan Kompres Tepid Water Sponge dengan uji Paired-Samples T Test

\begin{tabular}{lccc}
\hline \multicolumn{1}{c}{ Variabel } & Mean & p-value & n \\
\hline $\begin{array}{l}\text { Suhu sebelum } \\
\text { tindakan }\end{array}$ & 38,61 & & \\
\cline { 1 - 2 } $\begin{array}{l}\text { Suhu 30 menit } \\
\text { setelah tindakan }\end{array}$ & 37,6167 & & \\
\hline
\end{tabular}


Tabel 9 menunjukkan hasil uji hipotesis didapat nilai signifikan $p=0,0001(p<0,05)$ berarti hipotesis ditolak, artinya terdapat perbedaan suhu tubuh yang bermakna antara sebelum dan setelah dilakukan tindakan kompres tepid water sponge.

Tabel 10. Hasil Analisis Suhu Tubuh Responden Sebelum dan Setelah Tindakan Kompres Hangat dengan uji Paired-Samples T Test

\begin{tabular}{lccc}
\hline \multicolumn{1}{c}{ Variabel } & Mean & p-value & n \\
\cline { 1 - 2 } $\begin{array}{l}\text { Suhu sebelum } \\
\text { tindakan }\end{array}$ & 38,3833 & & \\
$\begin{array}{lll}\text { Suhu 30 menit } \\
\text { setelah tindakan }\end{array}$ & 37,8433 & 0,0001 & 20 \\
\cline { 1 - 2 } & & & \\
\hline
\end{tabular}

Tabel 10 menunjukkan hasil uji hipotesis didapat nilai signifikan $p=0,0001(p<0,05)$ berarti hipotesis ditolak, artinya terdapat perbedaan suhu tubuh yang bermakna antara sebelum dan setelah dilakukan tindakan kompres hangat.

Tabel 11. Hasil Analisis Efektivitas Pengaturan Suhu Tubuh dengan Kompres Tepid Water Sponge dan Kompres Hangat dengan menggunakan uji Independent Samples T Test

\begin{tabular}{lccc}
\hline \multicolumn{1}{c}{ Variabel } & Mean & p value & n \\
\cline { 1 - 2 } $\begin{array}{l}\text { Perbedaan suhu kompres } \\
\text { tepid water sponge }\end{array}$ & 0,993 & & \\
$\begin{array}{llll}\text { Perbedaan suhu kompres } \\
\text { hangat }\end{array}$ & 0,0001 & 30 \\
\hline
\end{tabular}

Tabel 11 menunjukkan hasil uji hipotesis didapat nilai signifikan $p=0,0001(p<0,05)$ berarti hipotesis ditolak, artinya terdapat perbedaan efektivitas pengaturan suhu tubuh dengan metode kompres hangat dan kompres tepid water sponge. Kompres hangat memberikan penurunan suhu tubuh sebesar $0,54^{\circ} \mathrm{C}$ atau dibulatkan menjadi $0,5^{\circ} \mathrm{C}$, sedangkan kompres tepid water sponge memberikan penurunan suhu tubuh sebesar $0,993^{\circ} \mathrm{C}$ atau dibulatkan menjadi $1^{\circ} \mathrm{C}$.

Masing-masing responden dilakukan pengukuran suhu tubuh sebelum diberikan tindakan kompres hangat dan kompres tepid water sponge. Berdasarkan hasil penelitian pada kelompok kompres tepid water sponge diperoleh rata-rata suhu tubuh sebelum tindakan dari 30 responden yaitu sebesar $38,61^{\circ} \mathrm{C}$ atau jika dibulatkan menjadi $38,6^{\circ} \mathrm{C}$ dengan suhu minimum yaitu $37,8^{\circ} \mathrm{C}$ dan suhu maksimum yaitu $39,5^{\circ} \mathrm{C}$. Hasil penelitian pada kelompok kompres air hangat diperoleh rata-rata suhu tubuh sebelum tindakan dari 30 responden yaitu sebesar $38,38^{\circ} \mathrm{C}$ atau jika dibulatkan menjadi $38,4^{\circ} \mathrm{C}$, dengan suhu minimum yaitu $37,7^{\circ} \mathrm{C}$ dan suhu maksimum yaitu $39,2^{0} \mathrm{C}$.

\section{PEMBAHASAN}

Anak usia di bawah lima tahun (balita) merupakan kelompok yang rentan terhadap gangguan kesehatan sehingga membutuhkan perhatian dan pemantauan secara khusus terhadap status kesehatan (Noviyanti, 2010). Kondisi anak dari sehat menjadi sakit mengakibatkan tubuh bereaksi untuk meningkatkan suhu yang disebut sebagai demam (Hamid, 2011). Ikatan Dokter Anak Indonesia menetapkan suhu tubuh normal untuk anak berkisar antara $36,5^{\circ} \mathrm{C}$ sampai $37,5^{\circ} \mathrm{C}$. Demam merupakan kondisi terjadinya kenaikan suhu tubuh hingga $>37,5^{\circ} \mathrm{C}$ (Setiawati, 2009). Pengukuran suhu dilakukan dengan menggunakan termometer air raksa karena termometer tersebut tidak bergantung pada sumber energi apapun sehingga pengukuran dengan cara yang benar akan selalu sama ketepatannya (Handy, 2016).

Kompres adalah salah satu tindakan non farmakologis untuk menurunkan suhu tubuh bila anak mengalami demam. Ada beberapa macam kompres yang bisa diberikan untuk menurunkan suhu tubuh yaitu tepid water sponge dan kompres air hangat (Dewi, 2016).

Studi pada kelompok tepid water sponge didapatkan hasil terjadi penurunan rata-rata suhu setelah dilakukan tindakan. Rata-rata suhu tubuh sebelum tindakan yaitu $38,61^{\circ} \mathrm{C}$ atau dibulatkan menjadi $38,6^{\circ} \mathrm{C}$ dan rata-rata suhu 30 menit setelah dilakukan tindakan kompres tepid water sponge yaitu $37,61^{\circ} \mathrm{C}$ atau dibulatkan menjadi $37,6^{\circ} \mathrm{C}$.

Hasil penelitian ini menyatakan terjadi penurunan rata-rata setelah dilakukan tindakan kompres tepid water sponge, senada dengan hasil penelitian Bartolomeus Maling yang menyatakan ada pengaruh kompres tepid water sponge terhadap penurunan suhu tubuh anak usia 1-10 tahun yang mengalami demam (Maling, 2012). Hasil penelitian ini diperkuat dengan kesimpulan dari penelitian Siti Haryani, Eka Adimayanti, Ana Puji Astuti yang menyatakan kompres tepid water sponge berpengaruh pada penurunan suhu tubuh (Haryani, 2018).

Hal tersebut senada dengan penelitian yang dilakukan oleh João Guilherme Bezerra Alves; Natália Dornelas Câmara Marques de Almeida; Camila Dornelas Câmara Marques de Almeida bahwa tepid sponge lebih efektif 15 menit pertama dibandingkan jika hanya diberikan obat dypirone saja (Alves, 2008).

Teknik tepid water sponge berpengaruh terhadap penurunan suhu tubuh karena kompres blok langsung dilakukan di beberapa tempat yang memiliki pembuluh darah besar, sehingga mengakibatkan peningkatan sirkulasi serta 
peningkatan tekanan kapiler. Tekanan $\mathrm{O}_{2}$ dan $\mathrm{CO}_{2}$ dalam darah akan meningkat dan $\mathrm{pH}$ dalam darah turun (Hamid, 2011). Tepid water sponge juga dilakukan dengan cara menyeka seluruh tubuh klien dengan air hangat (Kusnanto, 2008). Teknik kompres tepid water sponge dapat mempercepat vasodilatasi pembuluh darah perifer di seluruh tubuh sehingga pengeluaran panas dari tubuh melalui kulit lebih cepat dibandingkan teknik kompres air hangat yang hanya pada daerah tertentu. Teknik kompres tepid water sponge lebih cepat memberikan rangsangan atau sinyal ke hipotalamus melalui sumsum tulang belakang. Ketika reseptor yang peka terhadap panas di hipotalamus dirangsang, sistem efektor mengeluarkan sinyal melalui berkeringat dan vasodilatasi perifer. Perubahan pembuluh darah diatur oleh pusat vasometer pada medulla oblongata dari tangkai otak di bawah pengaruh hipotalamus bagian anterior sehingga terjadi vasodilatasi. Dengan terjadinya vasodilatasi ini menyebabkan pembuangan atau kehilangan energi panas melalui kulit meningkat (yang ditandai dengan tubuh mengeluarkan keringat), kemudian suhu tubuh dapat menurun atau normal (Potter, 2005).

Hasil penelitian pada kelompok kompres hangat juga didapatkan hasil terjadi penurunan rata-rata suhu setelah dilakukan tindakan. Ratarata suhu tubuh sebelum dilakukan tindakan yaitu $38,38^{\circ} \mathrm{C}$ atau dibulatkan menjadi $38,4^{\circ} \mathrm{C}$ dan ratarata suhu 30 menit setelah dilakukan tindakan kompres hangat yaitu $37,843^{\circ} \mathrm{C}$ atau dibulatkan menjadi $37,8^{\circ} \mathrm{C}$.

Kompres air hangat dapat menurunkan suhu tubuh melalui proses evaporasi. Dengan kompres air hangat menyebabkan suhu tubuh di luar akan hangat sehingga tubuh akan menginterpretasikan bahwa suhu di luar cukup panas, akhirnya tubuh akan menurunkan kontrol pengatur suhu di otak supaya tidak meningkatkan suhu pengatur tubuh, dengan suhu di luar hangat akan membuat pembuluh darah tepi di kulit melebar dan mengalami vasodilatasi sehingga pori-pori kulit akan membuka dan mempermudah pengeluaran panas sehingga akan terjadi penurunan suhu tubuh (Dewi, 2016). Senada dengan hasil penelitian Aminatul Fatayati yang menyatakan ada pengaruh kompres hangat terhadap penurunan suhu tubuh pada balita demam (Fatayati, 2010).

Mekanisme kerja dari tepid water sponge sama dengan kompres hangat pada umumnya, namun dengan teknik yang sedikit dimodifikasi yaitu dengan menggabungkan teknik blok dan seka (Efendi, 2012).
Setelah 15 menit dilakukan tindakan kompres tepid water sponge dan kompres hangat, suhu kembali diukur dengan menggunakan termometer air raksa. Berdasarkan hasil penelitian diperoleh rata-rata suhu 15 menit setelah tindakan pada kelompok tepid water sponge yaitu sebesar $38,11^{\circ} \mathrm{C}$ atau dibulatkan menjadi $38,1^{\circ} \mathrm{C}$, dengan suhu minimum yaitu $37,4^{\circ} \mathrm{C}$ dan suhu maksimum yaitu $39^{\circ} \mathrm{C}$. Hasil penelitian pada kelompok kompres hangat diperoleh rata-rata suhu 15 menit setelah tindakan yaitu sebesar $38,03^{\circ} \mathrm{C}$ atau jika dibulatkan menjadi $38^{\circ} \mathrm{C}$ dengan suhu minimum yaitu $37,4^{\circ} \mathrm{C}$ dan suhu maksimum yaitu $39^{\circ} \mathrm{C}$.

Hasil penelitian tersebut senada dengan hasil penelitian Arie Kusumo Dewi yang menyatakan ada perbedaan yang signifikan antara suhu sebelum tindakan dan suhu setelah dilakukan kompres air hangat dan tepid sponge bath, serta ada perbedaan penurunan suhu tubuh antara pemberian kompres air hangat dan tepid sponge bath pada anak demam (Dewi, 2016).

Berdasarkan hasil penelitian pada kelompok tepid water sponge didapatkan ratarata penurunan suhu tubuh sebesar $0,99^{\circ} \mathrm{C}$ atau dibulatkan menjadi $1{ }^{\circ} \mathrm{C}$, sedangkan rata-rata penurunan suhu tubuh pada kelompok kompres hangat yaitu sebesar $0,5^{\circ} \mathrm{C}$.

Penelitian serupa mengenai efektifitas tepid water sponge dan kompres hangat, juga dilakukan oleh Aryanti Wardiyah, Setiawati, Umi Romayati. Didapatkan hasil bahwa metode tepid water sponge lebih efektif dibandingkan kompres hangat dalam membantu menurunkan suhu tubuh anak, dimana dengan metode tepid water sponge rata-rata penurunan suhu sebesar $0,8^{\circ} \mathrm{C}$. Sedangkan dengan kompres hangat rata-rata penurunan suhu sebesar $0,5^{\circ} \mathrm{C}$ (Wardiyah, 2016). Hasil tersebut senada dengan hasil penelitian Memed Isneini, Irdawati, Agustaria, dimana didapatkan hasil rata-rata penurunan suhu tubuh dengan metode tepid water sponge sebesar $0,5^{\circ} \mathrm{C}$ dan rata-rata penurunan suhu tubuh dengan kompres hangat sebesar $0,2^{0} \mathrm{C}$ (Isneini, 2014).

Tepid water sponge merupakan alternatif teknik kompres yang menggabungkan teknik blok dan seka (Efendi, 2012). Kompres hangat merupakan tindakan menurunkan suhu tubuh dengan menggunakan kain atau handuk yang telah dicelupkan pada air hangat, yang ditempelkan pada bagian tubuh tertentu sehingga dapat memberikan rasa nyaman (Wardiyah, 2016).

Memberikan kompres pada anak-anak yang mengalami demam adalah hal yang terbiasa dilakukan orang tua pada anak-anak mereka. Ketika anak demam, tentu diperlukan tindakan 
yang dapat membantu proses penurunan suhu tubuhnya. Dari penelitian di atas dapat diketahui keunggulan metode tepid water sponge. Pengetahuan ini akan menjadi sangat berarti bagi orang tua, untuk mengatasi anak mereka yang sedang mengalami demam.

Pemberian tindakan pada metode tepid water sponge, pada langkah awal, hampir sama dengan pemberian kompres hangat. Diawali dengan mengompres pada lima titik (leher, 2 ketiak, dan 2 pangkal paha). Kemudian dilanjutkan dengan menyeka bagian perut dan dada, atau seluruh badan dengan air hangat menggunakan kain atau handuk kecil. Basahi kembali kain, ketika sudah kering.

Metode tepid water sponge bekerja dengan memperlebar (vasodilatasi) pembuluh darah perifer di seluruh tubuh. Ini menyebabkan evaporasi dan konduksi panas dari kulit ke lingkungan sekitar akan lebih cepat. Jika dibandingkan dengan kompres hangat yang menurunkan panas dengan mengandalkan reaksi dari rangsangan hipotalamus.

Perawat di tatanan layanan kesehatan, baik di puskesmas, rumah sakit, dapat mengajarkan hal ini pada setiap orang tua yang anaknya dirawat dengan demam. Harapannya para orang tua dapat menangani dengan segera ketika dihadapkan pada masalah kenaikan suhu tubuh anak. Tentu upaya penanggulangan yang cepat akan dapat membantu proses pemulihan dan mengurangi kemungkinan cedera lebih lanjut.

Cara ini dapat dikatakan sangat sederhana dengan hasil yang baik sekali, serta dapat dilakukan dengan mudah oleh orang tua di rumah. Perawat sebagai educator bagi pasien anak dan keluarga, memiliki peran yang sangat penting dalam proses pembelajaran orang tua ini. Apalagi demam pada anak-anak di bawah usia lima tahun, adalah hal yang perlu mendapat penanganan serius. Kita ketahui demam pada anak balita, berbeda pada demam anak usia lebih tua, apalagi orang dewasa. Demam tinggi pada balita, dapat mengalami komplikasi yang lain, seperti kejang.

Tentu ada beberapa hal yang menjadi catatan perawat, ketika melaksanakan dan mengajarkan metode tepid water sponge ini. Seperti keadaan umum anak, respon anak selama pemberian tindakan. Mencermati hasil yang diberikan dari metode tepid water sponge ini, seyogyanya menjadi masukan bagi pemberian asuhan keperawatan di fasilitas layanan kesehatan dalam menangani demam pada anak, balita khususnya.

Berdasarkan penelitian ini, dapat disimpulkan bahwa metode tepid water sponge lebih efektif digunakan dalam mempercepat penurunan suhu tubuh dibandingkan kompres hangat.

Penelitian ini masih memiliki banyak kekurangan, baik yang disebabkan oleh keterbatasan penulis sendiri dari segi waktu maupun kondisi. Pada penelitian selanjutnya, tentu dengan jumlah sampel yang lebih besar, akan dapat memberikan informasi yang lebih lengkap.

\section{SIMPULAN}

Rata-rata suhu tubuh sebelum tindakan kompres tepid water sponge yaitu $38,5^{\circ} \mathrm{C}$. Ratarata suhu tubuh sebelum tindakan kompres hangat yaitu $38,3^{\circ} \mathrm{C}$.

Rata-rata suhu 15 menit setelah tindakan kompres tepid water sponge yaitu $38^{\circ} \mathrm{C}$ dan ratarata suhu 30 menit setelah tindakan kompres tepid water sponge yaitu $37,5^{\circ} \mathrm{C}$. Rata-rata suhu 15 menit setelah tindakan kompres hangat yaitu $38^{\circ} \mathrm{C}$ dan rata-rata suhu 30 menit setelah tindakan kompres hangat yaitu $37,8^{\circ} \mathrm{C}$.

Terdapat perbedaan suhu tubuh sebelum dan setelah pemberian tindakan kompres tepid water sponge dan kompres hangat dengan hasil uji statistik yaitu nilai signifikan $p=0,000$ yang berarti $p<0,05$ maka Ho ditolak.

Terdapat perbedaan efektivitas pengaturan suhu tubuh dengan metode kompres tepid water sponge dan kompres hangat. Hasil uji statistik yaitu nilai signifikan $(p)=0,000$ yang berarti $p<0,05$ maka $\mathrm{H}_{0}$ ditolak. Kompres hangat memberikan penurunan suhu tubuh sebesar $0,54^{\circ} \mathrm{C}$ atau dibulatkan menjadi $0,5^{\circ} \mathrm{C}$, sedangkan kompres tepid water sponge memberikan penurunan suhu tubuh sebesar $0,993^{\circ} \mathrm{C}$ atau dibulatkan menjadi $1^{0} \mathrm{C}$.

\section{DAFTAR PUSTAKA}

Alves, J. G. B., Almeida, N. D. C. M. de and Camila Dornelas Câmara Marques de Almeida. (2008). Tepid sponging plus dipyrone versus dipyrone alone for

reducing body temperature in febrile children. Sao Paulo Medical Journal, 126(2), pp. 107-111. doi: 10.1590/S151631802008000200008 . 
Dewi, A. K. (2016). Perbedaan Penurunan Suhu Tubuh antara Pemberian Kompres Hangat dengan Tepid Sponge Bath pada Anak Demam. Jurnal Keperawatan Muhammadiyah, 1(1):63-71.

Dinas Kesehatan Provinsi Bali. (2016). Profil Kesehatan Provinsi Bali Tahun 2016. http://www.diskes.baliprov.go.id/files/subd omain/diskes/September

2017/Profil_Kesehatan_Bali_2016.pdf.

diakses tanggal 15 November 2017

Efendi, D. (2012). Perbedaan Efektifitas Kompres Hangat Teknik Blok Aksila Dengan Kompres Hangat Tepid Sponge Terhadap Penurunan Suhu Pada Anak Dengan Demam Di Ruang Anak RSUD. Dr. Soebandi Jember dan Dr. H. Koesnadi Bondowoso. The Indonesian Journal of Health Science, 3(1):50-59.

Fatayati, A. (2010). Pengaruh Pemberian Kompres Hangat Terhadap Penurunan Suhu Badan Pada Balita Dengan Demam Di RS PKU Muhammadiyah Yogyakarta Tahun 2010. (Karya Tulis Ilmiah, Universitas 'Aisyiyah Yogyakarta).

Ganong, W. F. (2002). Fisiologi Kedokteran. Jakarta: EGC.

Hamid, M. A. (2011). Keefektifan Kompres Tepid Sponge Yang Ilakukan Ibu Dalam Menurunkan Demam Padaanak: Randomized Control Trial Di Puskesmas Mumbulsari Kabupaten Jember. (Tesis, Universitas Sebelas Maret).

Handy, F. (2016). A-Z Penyakit Langganan Anak. 1st edn. Jakarta: Pustaka Bunda.

Haryani, S., Adimayanti, E. dan Astuti, A. P. (2018). Pengaruh Tepid Sponge terhadap Penurunan Suhu Tubuh pada Anak Pra Sekolah yang Mengalami Demam di RSUD Ungaran. Jurnal Keperawatan dan Kesehatan Masyarakat Cendekia Utama, 7(1), 44-53.

Isneini, M., Irdawati dan Agustaria. (2014). Efektifitas Penurunan Suhu Tubuh Antara Kompres Hangat dan Water Tepid Sponge Pada Pasien Anak Usia 6 Bulan - 3 Tahun Dengan Demam Di Puskesmas Kartasura Sukuharjo. (Skripsi, Fakultass Ilmu Kesehatan, Universitas Muhammadiyah Surakarta). http://eprints.ums.ac.id/32263/

Kania, N. (2007). Penatalaksanaan Demam Pada
Anak. Bandung: Pustaka UNPAD.

Kusnanto, Widyawati, I. Y. dan Cahyanti, I. S. (2008). Efektifitas Tepid Sponge Bath Suhu $32^{\circ} \mathrm{C}$ dan $37^{\circ} \mathrm{C}$ Dalam Menurunkan Suhu Tubuh Anak Demam. Jurnal Ners. 3(1) : 1-7.

Mahdiyah, D., \& RAHMAN, R. T. A. (2015). Perbedaan Efektifitas Kompres Hangat Basah Dan Plester Kompres Terhadap Penuruan Suhu Tubuh Anak Demam Typhoid. DINAMIKA KESEHATAN JURNAL KEBIDANAN DAN KEPERAWATAN, 6(1), 35-47.

Maling, B. (2012). Pengaruh Kompres Tepid Sponge Hangat Terhadap Penurunan Suhu Tubuh Pada Anak Umur 1-10 Tahun Dengan Hipertermia (Studi Kasus Di RSUD Tugurejo Semarang). Karya Ilmiah, S.1 Keperawatan, Sekolah Tinggi Ilmu Kesehatan Telogorejo.

Noviyanti, R. D. dan Sarbini, D. (2010). Hubungan Status Gizi Dengan Status Imunitas Anak Balita Di RW VII Kelurahan Sewu, Kecamatan Jebres, Kota Surakarta. Jurnal Kesehatan. 3(1) : 58-65.

Potter, Patricia A \& Perry, A. G. (2005). Buku Ajar Fundamental Keperawatan. 4th edn. Jakarta: EGC.

Sugiyono. (2015). Metode Penelitian, Kuantitatif, Kualitatif, dan $R \& D$. Bandung: Alfabeta.

Setiawati, T. (2009). Pengaruh tepid sponge terhadap penurunan suhu tubuh dan kenyamanan pada anak usia pra sekolah dan sekolah yang mengalai demam di ruang perawatan anak Rumah Sakit Muhammadiyah Bandung. (Tesis, Fakultas Ilmu Keperawatan, Universitas Indonesia.).

Thomas, S. et al. (2009). Comparative effectiveness of tepid sponging and antipyretic drug versus only antipyretic drug in the management of fever among children: A randomized controlled trial. Indian pediatrics. 46:133-136.

Wardiyah, A., Setiawati dan Romayati, U. (2016). Perbandingan Efektifitas Pemberian Kompres Hangat Dan Tepid Sponge Terhadap Penurunan Suhu Tubuh Anak Yang Mengalami Demam Di Ruang Alamanda RSUD Dr . H . Abdul Moeloek Provinsi Lampung Tahun 2015. Holistik Jurnal Kesehatan. 10(1): 36-44. 